\title{
Evaluating Iranian and non-Iranian English books in ELT from a cultural point of view
}

\author{
Zahra Ahmadi \\ MA student in TEFL, Science and Research Branch, Arak Azad University, Iran
}

\section{Email address:}

ahmadin.iran@gmil.com

To cite this article:

Zahra Ahmadi. Evaluating Iranian and Non-Iranian English Books in ELT from a Cultural Point of View. International Journal of Language and Linguistics. Special Issue: Language Teaching and Learning Key Principles (LTLKP). Vol. 1, No. 4-1, 2013 , pp. $20-25$. doi: $10.11648 /$ j.ijll.s.20130101.14

\begin{abstract}
The current study was designed to explore the importance of culture in teaching English and how well cultures and cultural related topics had been taken into account in Iranian and non-Iranian English books in ELT. Moreover, Iranian or non-Iranian books, had appreciated cultural subjects in terms of sport, place, religion, tradition, drink and job in content of the books as it was expected. Therefore, the study defined culture and considered impact of culture in learning a language and assessment of a book in ELT as well. The result indicated that non-Iranian English books had paid much more attention to using culture in their books.
\end{abstract}

Keywords: Culture, Acculturation, Iranian and Non-Iranian English Textbooks

\section{Introduction}

Today because of the vast array of textbooks to choose from, the textbook selection process often gravitates to one of two extremes. In the process of evaluating textbooks, some educators ask so many questions that they are never able to complete the process. Others choose a textbook with little or no evaluation, yet it becomes the centerpiece of the curriculum until another haphazardly chosen reader replaces it. This project is going to compare both text books completed by both English native and non-native speakers to see what cultural aspects are taken into account more and more.

The term 'culture' refers to the total of the inherited ideas, beliefs, values, and knowledge, which constitute the shared basis of social action. This system is acquired socially and organized in our minds in culture specific ways forming a framework, which largely determines the way we perceive and define the world around us (Alptekin, 1993).

Acculturation explains the process of cultural and psychological changes that results in meeting between cultures. The effects of acculturation can be seen at multiple levels in both interacting cultures. The transactional nature of acculturation is particularly notable in the evolution of languages. In some instances, acculturation results in the adoption of another country's culture, which is then modified over time to become a new, distinct, culture.

Language is used both as a means of communication as well as a carrier of culture. Language without culture is unthinkable, so is human culture without language (Wei, 2005). Moreover, linguistic competence alone is not enough for learners of a language to be competent in that language (Krasner, 1999).

Since culture and language are inseparable, English cannot be taught without the culture in which it is embedded. It is often suggested that, instead of the context of target culture, ELT should make use of contexts familiar to language learners.

Wei (2005) proposes to make our students aware of our own culture instead of spreading and teaching merely American or British culture in EFL classroom. Since studies on one's own culture EFL classrooms, learners may be more aware of cultural differences and therefore keep their cultural identity in cross-cultural communication.

Any educational system is composed of five important components (students, a teacher, materials, teaching methods, and evaluation) which are closely interrelated. Even in the context of communicative language teaching, teachers and learners tend to rely heavily on prescribed textbooks, which are still a staple in most of EFL classes (Ghorbani, 2009). 
With such background information on importance of English textbooks, this study seeks to find out how Iranian and non-Iranian insert and appreciate their culture in their textbooks.

According to Wei (2005:56), language has a dual character: both as a means of communication and a carrier of culture. Language without culture is unthinkable. A particular language is a mirror of a particular culture. Previous studies on culture and evaluation English textbooks investigated the teaching culture in English language classrooms, relationship between culture and ELT and evaluation in EFl context. According to Rahimpour (2011), that has worked on evaluation in EFl context, textbooks are not acceptable from the teachers' point of view their physical make-up, and some practical concerns. According to Tomalin (2008), the international role of the English language and globalization are the two main reasons to teach culture as a fifth language skill, in addition to listening, speaking, reading and writing. According to Sardi (2002), in the literature, one can find two widely spread and opposing views regarding the relationship between culture and ELT.

First, culture and language are inseparable; therefore, English Culture and language are inseparable, therefore, English cannot be taught without its culture. Second, English teaching should be carried out independently of its cultural context. Instead, contexts familiar to the students should be used.

\section{Significance of Study}

The importance and superiority of this article over other articles which have been published in cultural context is that native and non-native textbooks have not been compared and evaluated through cultural aspects so far; therefore, this study aims at comparison and contrast between Iranian and non-Iranian books from cultural point of view. Although English textbooks in TFL have been evaluated in different facets, the comparison between Iranian and non-Iranian, native and non-native, textbooks has not been investigated.

\section{Research Question and Hypothesis}

In order to facilitate the investigation regarding the evaluation of the EFL books, Iranian and non-Iranian, the researcher formulated the following research question and hypothesis.

Q1: Are Iranian EFL books more successful in inserting and valuing cultural subjects or non-Iranian's?

Taking this question into account, the following nullhypothesis is proposed:

H0: Neither Iranian EFL books nor non-Iranian's are successful in inserting and valuing cultural subjects.

\section{Methodology}

\subsection{Materials}

For the purpose of data collection:

Current Iranian ELT textbooks were taken to serve as the corpus of present study.

English Book 1, 2, 3(Birjandi, Soheili 2005) that is locally designed to cater for and respond to the English language needs of Iranian students in grade 1, 2, 3 at junior high schools. English Book 1, 2, 3 (Birjandi, Noruzi and Mahmodi 2006) that is locally designed to use in grade 1, 2, 3 at senior high schools. English Book for pre-university students (Birjandi, Ananisarab, Samimi 2009).

Non-Iranian ELT books:

Top Notch FA, FB, 1A, 1B, 2A, 2B, 3A, 3B, Summit1, Summit2 (Ascher \& Saslow 2006)

Interchange Intro, 1, 2, 3(Richards 2005). Tactics for Listening Basic, Developing, Expanding (Richards 2011). American English File 1, 2, 3(Oxenden, Koeing, Sligson 1997).

\subsection{Procedures}

The purpose of this study was to evaluate the Iranian and non-Iranian English language books from cultural point of view, to find out which one is more successful in imposing its culture in its books. In order to do so, the following steps were taken; qualitative approach for gathering and analyzing data was used in this study.

First, cultural subjects were categorized into eight groups: tradition, religion, place, food, sport, job, move \& TV programs, religion, beverage and music. Second, all Iranian EFL textbooks were investigated word by word and every cultural point was written under the specific sub-cultural categories, which were mentioned above. After that, this steps were taken for non-Iranian books as well. Then the result of both Iranian and non-Iranian books were compared and contrasted. Finally, the findings were indicated in three tables (1,2 and 3).In table 1, it was shown, which cultural points were used the most in Iranian books. In table 2 , the most usage of cultural subjects in non-Iranian books was considered. In table 3 , the first and the second table were illustrated together.

\section{Results and Discussion}

Kramsch (1993) argues that a foreign culture and one's own culture should be placed together in order for learners to understand a foreign culture. Learners' interaction with native speakers or text will require them to construct their own meanings rather than having educators simply transfer information about people and their culture, and therefore non-native speakers should have opportunities to make their own meanings and to reflect on both the target culture and their own. Kramsch (1993) refers to this as establishing a "sphere of interculturality".

Linguistic competence alone is not enough for learners 
of a language to be competent in that language (Krasner, 1999). Language learners need to be aware, for example, of the culturally appropriate ways to address people, express gratitude, make requests, and agree or disagree with someone. They should know that members of the target language speech community might perceive behavior and intonation patterns that are appropriate in their own speech community differently. They have to understand that, in order for communication to be successful, language use must be associated with other culturally appropriate behaviors (Peterson and Coltrane 2003).

Therefore, when learning a language, language learners have to acquire their native culture as much as the target culture to recognize the cultural clashes and differences in order to communicate successfully in foreign language. As long as textbooks are the basic components of EFL the native and target cultures should be taken into account in Iranian textbooks. As it is shown in following tables, nonIranian insert their culture more successfully than Iranian's.

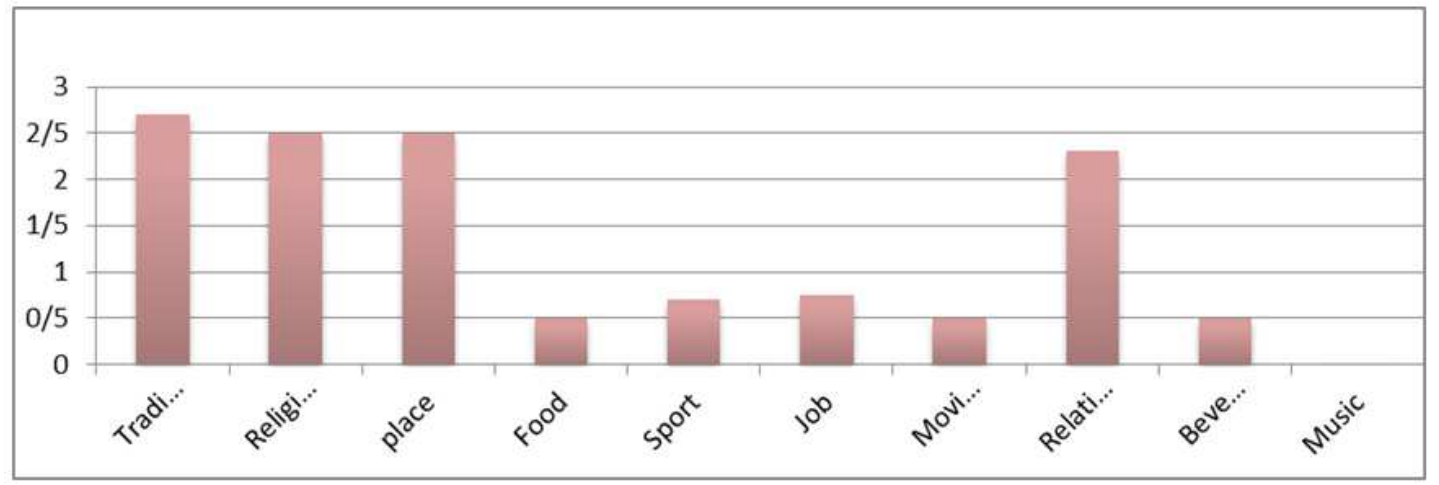

Chart 1: Iranian books

According to chart 1, Iranian textbooks have paid their to music and movies. most attention to religious subjects and their least attention

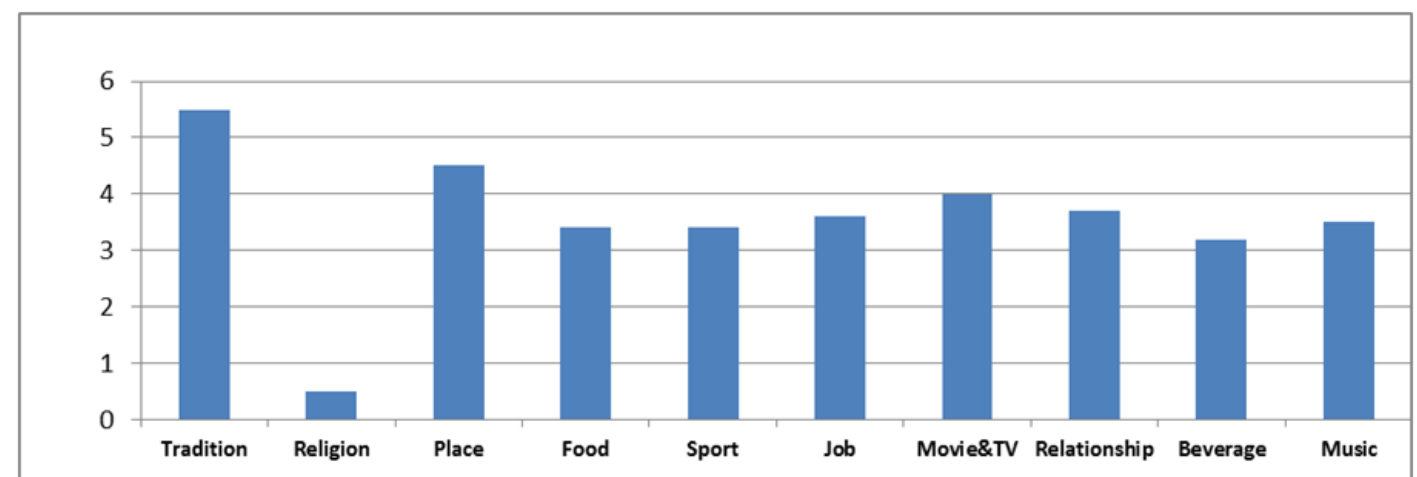

Chart 2: Non-Iranian books

According to chart 2, non-Iranian books have paid the their religion, although, the differences are not noticeable. most attention to their tradition and the least attention to

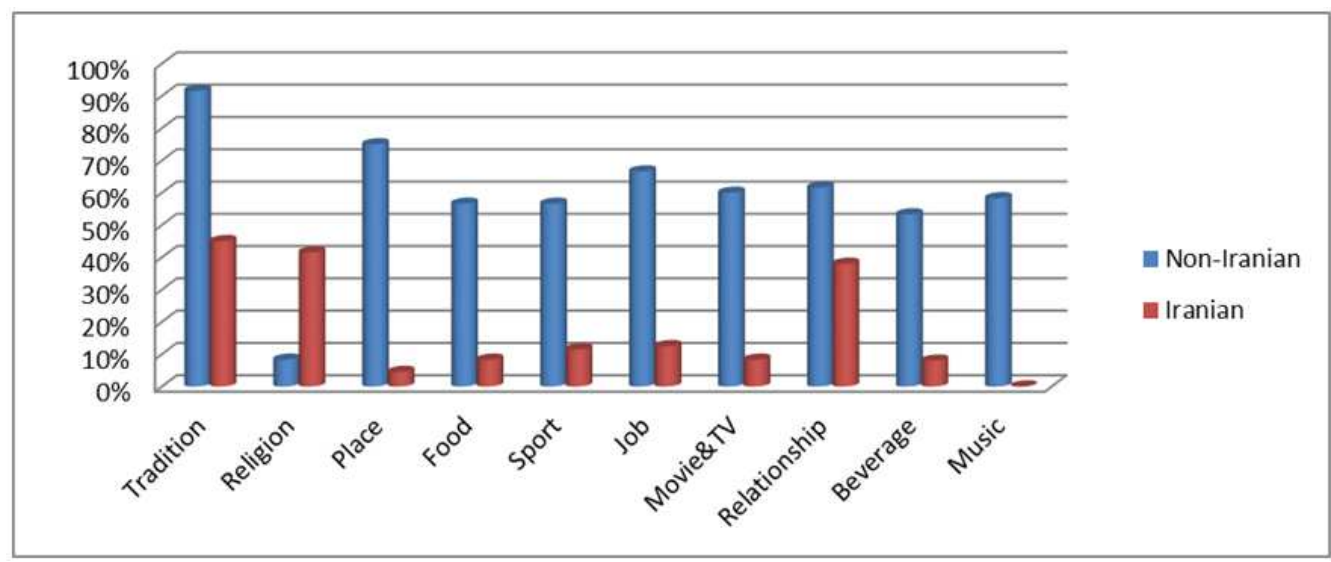

Chart 3: Iranian \& Non-Iranian 
According to chart 3, non-Iranian books were more successful in using and including different aspects of their culture in their books.

\section{Conclusion and Implication}

The present study took a contrastive pragmatic approach in using culture successfully in Iranian and non-Iranian ELT books. As mentioned earlier, according to Wei (2005:56), EFL teaching should lead to a better understanding of and an insight into one's native culture. Students must be provided with the necessary linguistic, communicative and intercultural skills to reflect upon and portray their own society, to express themselves, and to present their own culture in the target language. Besides, discussion can be initiated for the students to compare the underlying values and beliefs in students' native culture with the target culture so that students can not only know the difference but also better appreciate both cultures. In order to find out Iranian ELT books consider their cultural aspects more successfully or non-Iranian ELT books, these two kinds of books (native and non- native) were investigated through their cultural usage. According to chart 3,non-Iranian(native) textbooks had conveyed the ten subjects as follow: tradition $90 \%$, religion $8 \%$, place $80 \%$, food $55 \%$, sport $55 \%$, job $60 \%$, movie \& TV about $60 \%$, relationship $60 \%$, beverage $50 \%$ and music $55 \%$, while Iranian(non-native) textbooks have indicated the ten subjects as follow: tradition about $40 \%$, religion $40 \%$, place about $4 \%$, food $8 \%$, sport $10 \%$, job $10 \%$, movie \& TV about $8 \%$, relationship $35 \%$, beverage $7 \%$ and music $0 \%$.It was concluded that non-Iranian ELT books were much more successful in conveying their culture. On the contrary, Iranian ELT books were not successful in indicating their culture; therefore the null-hypothesis, neither Iranian EFL books nor non-Iranian's are successful in inserting and valuing cultural subjects, was rejected.

This study hopes that Ministry of Education revises the Iranian Curriculum in English language teaching and selects textbooks materials based on curriculum standards. English textbooks should be up-to-date and cultural subjects, like non-Iranian books, also should be included in textbooks.

\section{Appendices}

\section{A) Iranian Books}

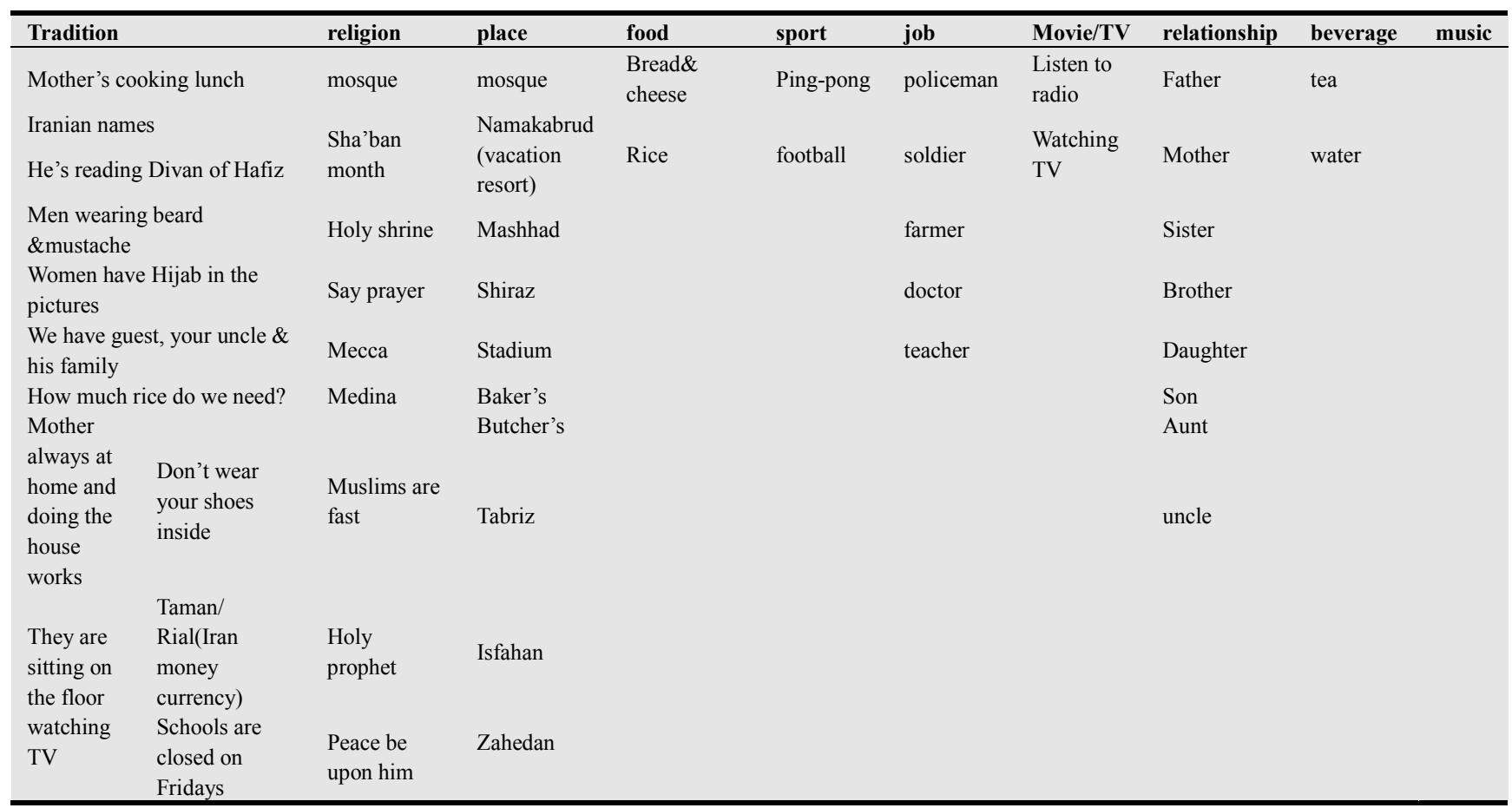

\section{B) Non-Iranian books}

\begin{tabular}{|c|c|c|c|c|c|c|c|c|c|}
\hline custom & religion & place & food & sport & job & $\begin{array}{l}\text { Movie/T } \\
\text { V }\end{array}$ & relationship & beverage & music \\
\hline $\begin{array}{l}\text { Play cards } \\
\text { wearing a tie } \\
\text { A typical American }\end{array}$ & $\begin{array}{l}\text { temple } \\
\text { church }\end{array}$ & $\begin{array}{l}\text { 4-toptourists } \\
\text { attractions } \\
\text { in NY city }\end{array}$ & $\begin{array}{l}\text { Pizza } \\
\text { French } \\
\text { fries }\end{array}$ & $\begin{array}{l}\text { Basketball } \\
\text { game } \\
\text { Football }\end{array}$ & $\begin{array}{l}\text { Actor } \\
\text { Actress } \\
\text { pilot }\end{array}$ & $\begin{array}{l}\text { MTV } \\
\text { Chanel } \\
\text { Fashion } \\
\text { Music }\end{array}$ & $\begin{array}{l}\text { Mother } \\
\text { Son }\end{array}$ & $\begin{array}{l}\text { Big } \\
\text { coffee } \\
\text { coca } \\
\text { milkshak }\end{array}$ & $\begin{array}{l}\text { Pop star } \\
\text { Play guitar } \\
\text { Record your }\end{array}$ \\
\hline
\end{tabular}




\begin{tabular}{|c|c|c|c|c|c|c|c|c|c|}
\hline custom & religion & place & food & sport & job & $\begin{array}{l}\text { Movie/T } \\
\text { V }\end{array}$ & relationship & beverage & music \\
\hline & & & & & & Videos & & e & song \\
\hline $\begin{array}{l}\text { getting a soothing } \\
\text { massage }\end{array}$ & & Coffee shop & spaghetti & $\begin{array}{l}\text { Hang } \\
\text { gliding }\end{array}$ & Athlete & & Daughter & water & \\
\hline fortune teller & & $\begin{array}{l}\text { Thai } \\
\text { restaurants }\end{array}$ & hamburger & Sky & Chef & $\begin{array}{l}\text { Western } \\
\text { Famous }\end{array}$ & colleague & green tea & \\
\hline $\begin{array}{l}\text { Different countries \& } \\
\text { their flags }\end{array}$ & & Hotel spa & steak & $\begin{array}{l}\text { Parachuti } \\
\text { ng }\end{array}$ & & Am- & Husband & $\begin{array}{l}\text { lemonad } \\
\text { e }\end{array}$ & $\begin{array}{l}\text { Mariachi } \\
\text { singers }\end{array}$ \\
\hline & & Jazz club & & Baseball & architect & movies & Wife & & \\
\hline $\begin{array}{l}\text { Smoking } \\
\text { Haunted hotel }\end{array}$ & & $\begin{array}{l}\text { The Louvre } \\
\text { museum }\end{array}$ & $\begin{array}{l}\text { cheeseburger } \\
\text { different }\end{array}$ & & $\begin{array}{l}\text { mechanic } \\
\text { hair } \\
\text { dresser }\end{array}$ & $\begin{array}{l}\text { Action, } \\
\text { Animated, }\end{array}$ & Boy/girl & & $\begin{array}{l}\text { Hip hop } \\
\text { style }\end{array}$ \\
\hline Fall in love & & Concerts & countries dish & & florist & Horror, & friend & & \\
\hline Love affair & & $\begin{array}{l}\text { Statue of } \\
\text { liberty }\end{array}$ & & & $\begin{array}{l}\text { dress } \\
\text { maker }\end{array}$ & Science- & Grand parents & & Tango \\
\hline First love & & Bar & & & $\begin{array}{l}\text { sales } \\
\text { person }\end{array}$ & $\begin{array}{l}\text { fiction } \\
\text { and }\end{array}$ & & & \\
\hline $\begin{array}{l}\text { Dress code in } \\
\text { different countries } \\
\text { Have a date with }\end{array}$ & & $\begin{array}{l}\text { Recording } \\
\text { studio }\end{array}$ & & & lawyer & $\begin{array}{l}\text { Musical } \\
\text { movies } \\
\text { show }\end{array}$ & Sister & & \\
\hline $\begin{array}{l}\text { someone } \\
\text { superstitions }\end{array}$ & & $\begin{array}{l}\text { World's } \\
\text { great } \\
\text { museums }\end{array}$ & & & & $\begin{array}{l}\text { Fashion } \\
\text { Talent } \\
\text { show }\end{array}$ & Brother & & $\begin{array}{l}\text { Take African } \\
\text { dance \& } \\
\text { Samba }\end{array}$ \\
\hline $\begin{array}{l}\text { April food's } \\
\text { Day }\end{array}$ & & $\begin{array}{l}\text { The coldest, } \\
\text { highest, } \\
\text { hottest }\end{array}$ & & & & & & & \\
\hline Hollywood & & $\begin{array}{l}\text { places in the } \\
\text { world }\end{array}$ & & & & & $\begin{array}{l}\text { Step } \\
\text { father/mother }\end{array}$ & & \\
\hline Tipping & & $\begin{array}{l}\text { Going to the } \\
\text { movies }\end{array}$ & & & & & & & singing in the \\
\hline Weave through traffic & & Casino & & & politician & & & & shower \\
\hline Cut off other drivers & & $\begin{array}{l}\text { Travel } \\
\text { agency }\end{array}$ & & & & & $\begin{array}{l}\text { Half sister/ } \\
\text { brother }\end{array}$ & & \\
\hline Tailgating & & opera & & & & & oromer & & \\
\hline Wear make up & & Play & & & & & In-laws family & & \\
\hline Co-education & & Egypt & & & & & & & \\
\hline Buffet & & Holland & & & & & & & \\
\hline Pet & & Thailand & & & & & & & \\
\hline \multicolumn{10}{|l|}{ Getting tattoo } \\
\hline \multicolumn{10}{|l|}{ Halloween } \\
\hline \multicolumn{10}{|l|}{ Thanks giving } \\
\hline \multicolumn{10}{|l|}{ Christmas } \\
\hline \multicolumn{10}{|l|}{ Earth day } \\
\hline \multicolumn{10}{|l|}{ Independence day } \\
\hline \multicolumn{10}{|l|}{ Believing in ghosts } \\
\hline \multicolumn{10}{|l|}{ zodiac signs } \\
\hline \multicolumn{10}{|l|}{ Face/body piercing } \\
\hline \multicolumn{10}{|l|}{ Changing hair style } \\
\hline \multicolumn{10}{|l|}{ Cosmetic surgery } \\
\hline \multicolumn{10}{|l|}{ Freedom animals } \\
\hline \multicolumn{10}{|l|}{$\begin{array}{l}\text { Break up with } \\
\text { girl/boy friend }\end{array}$} \\
\hline \multicolumn{10}{|l|}{$\begin{array}{l}\text { Getting a } \\
\text { manicure/pedicure- } \\
\text { facial }\end{array}$} \\
\hline \multicolumn{10}{|l|}{ Cosmetic products } \\
\hline \multicolumn{10}{|l|}{ New year's Eve } \\
\hline \multicolumn{10}{|l|}{ Valentine's day } \\
\hline \multicolumn{10}{|l|}{ Famous people } \\
\hline \multicolumn{10}{|l|}{ Kiss in public } \\
\hline $\begin{array}{l}\text { Call your parents by } \\
\text { the 1st name }\end{array}$ & & & & & & & & & \\
\hline
\end{tabular}




\section{References}

[1] Alptekin, C.(1993).Target-Language Culture in EFL Materials.ELT Journal, 47/2, 136-143.

[2] Ascher, A,\& Saslow, J.(2006).Top Notch: today's world, FA. Tehran, Iran: Ghazal Publications.

[3] Ascher, A,\& Saslow, J.(2006).Top Notch: today's world, FB. Tehran, Iran: Ghazal Publications.

[4] Ascher, A,\& Saslow, J.(2006).Top Notch: today's world, 1A.Tehran, Iran: Ghazal Publications.

[5] Ascher, A,\& Saslow, J.(2006).Top Notch: today's world, 1B.Tehran, Iran: Ghazal Publications.

[6] Ascher, A,\& Saslow, J.(2006).Top Notch: today's world, 2A.Tehran, Iran: Ghazal Publications.

[7] Ascher, A,\& Saslow, J.(2006).Top Notch: today's world,2B.Tehran, Iran: Ghazal Publications.

[8] Ascher, A,\& Saslow, J.(2006).Top Notch: today's world, Summit1.Tehran, Iran: Ghazal Publications.

[9] Ascher, A,\& Saslow, J.(2006).Top Notch: today's world, Summit 2.Tehran, Iran: Ghazal Publications.

[10] Birjandi, P, Soheili,A. (2005). English Book 1. Iranian textbook publication and distribution. Tehran, Iran: Iranian.

[11] Birjandi, P, Noruzi, M, Mahmodi, G. (2006). English Book 2. Iranian textbook publication and distribution. Tehran, Iran: Iranian.

[12] Birjandi, P\& Ananisarab, M\& Samimi, D. (2006).English for pr-university students. Tehran, Iran: Iranian.
[13] Ghorbani,M.R.(2009).ELT in Iranian high schools in Iran,Malaysia and Japan: reflections on how texts influence use of prescribed textbooks. Reflections on English Language Teaching. 8(2),131-139.

[14] Kramsch, C. (1993). Context and culture in language teaching. Oxford: Oxford University Press.

[15] Krasner, I. (1999). The role of culture in language teaching. Dialog on Language Instruction, 13(1-2), 79-88.

[16] Oxenden, C, \& Koeing,C,\& Seligson,P.(1997). American English file. Oxford: University Press.

[17] Peterson, E., \& Coltrane, B. (2003). Culture in Second Language Teaching. ERIC Clearinghouse on Languages and Linguistics, EDO-FL-03-09.

[18] Rahimpour,M.(20011).Textbook selection and evaluation im EFL context. World Journal of Education, 1(2),62-68.

[19] Richards, J. C .(2011).Tactics for listening. Oxford: Oxford University Press.

[20] Richards, J. C .(2005). Interchange. Tehran, Iran: Javdane Publications.

[21] Sardi, C.(2002).On the relationship between culture and ELT.Studies about Languages, 3(3)101-107.

[22] Tomalin, B. (2008). Culture - the fifth language skill. Retrieved June 5,2013, from: http://www.teachingenglish.org.uk/think/articles/culturefifth-language-skill

[23] Wei, Y. (2005). Integrating Chinese Culture with TEFL in Chinese Classroom. Sino-US English Teaching, 2(7), 55-58. 